\title{
Pancreatic Intraepithelial Neoplasia-1B
}

National Cancer Institute

\section{Source}

National Cancer Institute. Pancreatic Intraepithelial Neoplasia-1B. NCI Thesaurus. Code C95430.

A pancreatic intraepithelial neoplasia characterized by the presence of tall columnar cells that form papillary, micropapillary, or basally pseudostratified architectural patterns. Mild cytological atypia is present. 